\title{
Offshore operations capabilities: an exploratory study
}

\author{
Vilmar Antonio Gonçalves Tondolo \\ UNISUL - Universidade do Sul de Santa Catarina \\ vtondolo@gmail.com \\ Hale Kaynak \\ The University of Texas Pan-American - UTPA \\ halekaynak@gmail.com \\ Yeda Swirski de Souza \\ UNISINOS - Universidade do Vale do Rio dos Sinos \\ yedasou@unisinos.br \\ Cláudia Cristina Bitencourt \\ UNISINOS - Universidade do Vale do Rio dos Sinos \\ claudiacb@unisinos.br
}

\begin{abstract}
To explore how companies develop capabilities for managing offshore operations, this study examines the offshore operations of three companies in Brazil, Denmark, and Germany. The research results provide valuable information on the types of offshore operations implemented by the companies, the strategic role of offshore operations, barriers to implementing offshore operations, capabilities developed by companies for implementing offshore operations, and the role of dynamic capabilities elements (paths, positions, and processes) in the development of capabilities for managing offshore operations.
\end{abstract}

Key words: Offshoring, Capabilities, Dynamic Capabilities; Operations, Development

\section{INTRODUCTION}

Offshoring is a growing operations practice worldwide. Over the last decade, companies have moved manufacturing operations abroad, primarily from developed to developing countries. This movement can be considered a strategy formulated in response to the increasing competitiveness of global markets. In recent years, companies have also moved services, high-skill, and core business activities overseas. This shift in offshoring to more complex operations may require the creation and implementation of new organizational practices that have implications for various organizational issues (Duke CIBER/Archstone Consulting, 2005, 2006; Duke CIBER/Booz Allen Hamilton Inc., 2007).

Although offshoring has been practiced by companies for a long time (Hagell III \& Brown, 2005; Lewin \& Peeters, 2006a; Niederman, 2005; Olsen, 2006; Stringfellow et al., 2007; Sturgeon \& Florida, 2000) academic efforts are needed to achieve a full understanding of this phenomenon. One of these efforts is to acquire a better understanding of the strategic aspects of offshoring. Offshoring has implications for the strategic management field because it may require new resources and the development of new or unfamiliar capabilities. Thus, offshoring can be considered an internal process as well as a business strategy for effective management of resources and firm-level capabilities (Doh, 2005). It is also a strategy conducted on a learning-by-doing basis. This aspect suggests that implementation of offshoring is achieved by a continuum of stages (Lewin \& Peeters, 2006a; Marskell et al., 2006), during which the development of capabilities makes an important contribution to the implementation and management of this process (Carmel \& Agarwal, 2002; Ellran et al., 2008; Levy, 2005; Lewin \& Peeters, 2006b; Venkatraman, 2004; Youngdahl \& Ramaswamy, 2008). The literature has suggested that capabilities development is important when undertaking more complex 
offshoring processes such as product development (Manning et al., 2008), and overcoming difficulties created by temporal and spatial distance between locally dispersed work teams (Levina, 2007; Levina \& Vaast, 2008).

Focusing on managerial and firm capabilities, the dynamic capabilities (DC) approach can be a useful perspective for examining how companies develop unique capabilities in offshoring (Doh, 2005). This study aims to explore how companies develop capabilities for managing offshore operations. It integrates DC as a main theory lens and offshore operations as organizational context. More specifically, this study defines DC as "a firm's ability to integrate, build, and reconfigure internal and external competencies to address rapidly changing environments" (Teece et al., 1997, p. 516). Such a concept emphasizes DC as a set of organizational processes that result in the development of specific capabilities to fit environmental conditions. To explore how companies develop capabilities for managing offshore operations, this study examines the offshore operations of three companies in Brazil, Denmark, and Germany. The qualitative data were collected through semistructured interviews with four managers of those companies.

This study has a twofold contribution to research. First, it explores how companies develop capabilities for managing offshore operations. Second, it explores the role of three DC elements (paths, positions, and processes), to be discussed later, on the development of such capabilities. This study also contributes to practice by providing insights into how companies have developed capabilities and which capabilities they have developed for managing offshore operations. This article is organized as follows. In the next section we present a theoretical background on offshore operations and DC. In section 3 we describe the methodological procedure adopted. In section 4 we present cases and cross-cases analysis. The paper concludes with discussion of the results as well as implications for researchers and managers.

\section{THEORETICAL BACKGROUND}

\subsection{Offshore operations}

Contrary to what is commonly believed, offshoring has been practiced by companies for a long time. Ford Motor Company started to produce abroad in 1904, and in Europe, German Daimler started to produce abroad in 1891 (Sturgeon \& Florida 2000). Thus, offshoring actually is not a new phenomenon (e.g. offshore plants, Moxon 1975). In the literature, however, the term "outsourcing" is sometimes inappropriately used for "offshore," and the types of offshore have not been clearly delineated. Outsourcing is a contractual agreement between a company and an external provider to obtain goods and/or services (De Vita \& Wang 2006). Offshore, however, can be defined as "the movement or relocation of domestic firm activities and operations abroad" (Bunyaratavej et al., 2008, p. 227). Thus, the main difference is that, in outsourcing, an external provider can be either in the same country or abroad, whereas offshore or offshore sourcing implies that the external provider is located abroad (Chakrabarty 2006a; Niederman 2005; Terjessen 2006).

The literature review reveals three types of offshoring: offshore outsourcing, offshore partnership and offshore captive (Jahns et al., 2006; Robinson \& Kalakota, 2004; Youngdahl et al., 2008). In this study, we define offshore outsourcing as a company's transfer of tasks or business functions (e.g. assembly) to a third party in a foreign country (e.g. Beugré \& Acar 2008; UNCTAD, 2004). We define offshore captive as a company's shifting tasks or business functions to its own facilities in a foreign country (e.g. Beugré \& Acar 2008; UNCTAD, 2004). We define offshore partnership as an interorganizational relationship that shares tasks or business functions (e.g. joint ventures) in a foreign country (e.g. Robinson \& Kalakota, 2004; Youngdhal et al., 2008).

As a managerial process, the spread of offshoring is due to the development of organizational and managerial capabilities to coordinate this process (Levy, 2005). Offshoring may be characterized as a learning-by-doing process evolving from experimental practice-based peripheral activities to core business activities. As noted earlier, this aspect suggests that implementation of offshoring is done in a continuum of stages based on learning and capability building (Lewin \& Peeters, 2006b; Maskell et al., 2006). Accumulated experience also contributes toward highskill offshoring activities (Hagel III, 2004).

The potential for achieving positive results of offshoring also depends on how companies carry out this process. Consequently, at more advanced stages of offshore operations companies must develop specific capabilities to manage offshore relationships and global networks (Askin \& Massini, 2008; Carmel \& Agarwal, 2002; Lewin \& Peeters, 2006b; 
Levina, 2007; Levy, 2005; Venkatraman, 2004). Capabilities development (e.g. coordination of globally dispersed activities) has allowed companies to employ more complex offshoring processes. It involves learning processes and identification of and adaptation to changing requirements of and opportunities for offshoring (Manning et al., 2008).

\subsection{Dynamic capabilities}

In the literature on strategy, Makadok (2001) highlights two approaches: resource-picking and capability-building, two approaches that aim at understanding how the managers generate economic rents for their businesses. The first approach is linked to the Resource-Based View (RBV), which says that businesses achieve better performance in relation to competitors through different resources. The second approach is linked to DC. The DC perspective suggests that firms achieve performance superior to their competitors through development of resources and capabilities (Makadok, 2001). The main issue in this second approach is the relationship between the development of new capabilities and organizational performance (Sapienza et al., 2006). In other words, the DC perspective extends the RBV argument by addressing how resources and capabilities can be created and how the current stock of resources and capabilities can be refreshed in changing environments (Ambrosini \& Bowman, 2009).

The DC approach includes an evolutionary vision, "Schumpeterian," of the competition among firms. For this reason, differences among firms are created by the new combinations of resources and capabilities developed by firms throughout their path (Teece et al., 1997). The DC perspective emphasizes two main elements: the dynamic and the capability. The term "dynamic" refers to the shifting character of the environment that requires strategic responses (e.g. renew competences), and the term "capability" refers to the role of strategic management in coping with changing environmental requirements by adapting the company internally (e.g. integrating, and reconfiguring internal and external organizational skills, resources, and functional competences) (Teece \& Pisano, 1994; Teece et al., 1997). For this reason, the main concern is the ability of the organization to develop high-level capabilities through its path to leverage and/or sustain superior performance (Helfat \& Peteraf, 2003; Marcus \& Anderson, 2006). From the DC perspective, development of resources and capabilities is internal to a firm. In this respect, Eisenhardt and Martin (2000) emphasize that internal processes are the sources of dynamic capabilities. The path of the organization leads to the accumulation of knowledge that is capable of generating new routines and processes (Sapienza et al., 2006). As discussed above, DC can be considered a dynamic perspective of a strategic resource approach.

This perspective was introduced by Teece et al. (1997). Since then, other definitions and concepts of DC have been offered in the literature. An analysis of these concepts makes it possible to point out the following aspects. First, the main result of DC is to allow firms to keep up with environmental changes by creating, renewing or integrating resources, assets, capabilities, competences, and routines. As Wang and Ahmed (2007, p. 40) argue, "capability development as an outcome of dynamic capabilities over time is frequently discussed and evidenced in empirical research." Second, different aspects of DC are emphasized: organizational process, behavioural orientation, high-level managerial activities, firm's ability, firm's capacity, firm's routines and processes, learning process, firm's activities, and patterns. Thus, it is impossible to argue that DC is based on just one or a few aspects of a firm. In others words, DC is considered a set of organizational aspects that allow companies to cope with new external and internal requirements.

This study utilizes a DC approach based on the studies by Teece et al. (1997) and Teece and Pisano (2004) (see Figure 1). The three specific aspects of DC are elements, firm-specific processes, and outcomes. These are common features; in other words, any company should present these aspects embedded in DC (Wang \& Ahmed, 2007). The three DC elements help determine a company's DC and distinctive competence as follow: (1) organizational processes, which entail the organizational and managerial routines of current practice and learning, (2) positions, which refers to a company's current endowment of technology and intellectual property and its relationships with customers, suppliers, and strategic alliances, and (3) paths, which refers to the strategic alternatives and opportunities available to the company.

Figure 1: A framework for developing capabilities to manage offshore operations 
Figure 1: A framework for developing capabilities to manage offshore operations

\begin{tabular}{|c|c|c|c|}
\hline $\begin{array}{l}\text { Offshoring Elements } \\
\text { - Type of offshore } \\
\text { operations } \\
\text { - Strategic role of } \\
\text { offshore operations } \\
\text { - Barriers to } \\
\text { implement/manage } \\
\text { offshore operations }\end{array}$ & $\begin{array}{l}\text { DC Elements } \\
\text { - Organizational } \\
\text { processes } \\
\text { - Paths } \\
\text { - Positions } \\
\underbrace{}_{\text {Dy }}\end{array}$ & $\begin{array}{l}\text { Firm Specific DC } \\
\quad \text { Processes } \\
\text { - Reconfiguration } \\
\text { - Leveraging } \\
\text { - Learning }\end{array}$ & $\begin{array}{c}\text { Outcomes } \\
\text { - Developed capabilities } \\
\text { to overcome barriers }\end{array}$ \\
\hline
\end{tabular}

In this study, firm-specific processes of DC entail reconfiguration, leveraging, and learning. These processes may vary among companies because they are developed over time (Wang \& Ahmed, 2007). In other words, they are path dependent. Reconfiguration is the recombination of resources and capabilities to fit with changing requirements (Ambrosini \& Bowman, 2009; Bowman \& Ambrosini, 2003; Eisenhardt \& Martin, 2000; Menon, 2008). Leveraging is the replication of a process or systems to another business unit (Ambrosini \& Bowman, 2009; Bowman \& Ambrosini, 2003). Learning is the creation and regeneration of new knowledge that allows a task to be performed (Ambrosini \& Bowman, 2009; Bowman \& Ambrosini, 2003; Menon, 2008). In this study, the outcome of DC is the development of capabilities for managing offshore operations. In other words, we refer to capability development as an outcome of a firm's dynamic capabilities over time. DC can be considered a higher-order capability (e.g. Collis \& Montgomery, 1994) or a dynamic ability (e.g. Zahra et al., 2006) that develops, reconfigures, renews, and integrates a company's capabilities. Therefore, this work focuses on DC as a set of processes for developing organizational capabilities (e.g. the capability for managing offshore operations). In doing so, this work does not discuss DC as a specific distinctive capability (e.g. R\&D).

\section{METHODOLOGY}

Because this study is exploratory, we employed the multiple case study research approach. Several studies have discussed the benefits and characteristics of this methodology (e.g. Eisenhardt, 1989; Meredith, 1998; Voss et al., 2002; Yin, 2003). By using multiple cases, for example, we can utilize our theory to highlight certain characteristics, and then find the differences and similarities among the cases (Yin, 2003). To ensure quality of data collection, three companies were selected. The main selection criterion was that companies have had offshore operations. The companies' headquarters are located in Brazil, Denmark, and Germany. In order to protect the identity of each company, we will refer to these companies as company $\mathrm{A}$, company $\mathrm{B}$, and company $\mathrm{C}$, respectively.

The data were collected through semi-structured interviews of executives who have had experience with offshore operations These interviews were conducted by phone and lasted from 50 to 70 minutes. All interviews utilized a protocol. This instrument was developed to ensure valid data was obtained, formalize the case study, and systemize the observation and analysis to increase reliability of the study (internal validity). The use of multiple sources enabled us to triangulate data as a means of validating and verifying the consistency of the data (Stake, 1998; Yin, 2003). To establish external validity, we used analytical generalization based on Yin's suggestions (2003).

To analyze the data we used the qualitative content analysis technique (Flick, 2002; Cooper \& Schindler, 2003). The main categories of analysis developed were the following: (1) strategic role of offshore operations, (2) barriers to the implementation of offshore operations, (3) capabilities developed by companies to manage and implement offshore operations, and (4) the role of dynamic capabilities elements (paths, positions, and processes) on the development of capabilities for managing offshore operations.

\section{CASES}

\subsection{Company A}

Company A is a Brazilian firm established in 1949 that produces a diverse line of coaches used for public transportation. Company A has more than 12,000 employees and operations in multiple countries in 
addition to Brazil: Argentina, Colombia, Mexico, India, Russia, Egypt, South Africa, and Portugal. It started offshore operations in 1990 with the establishment of a captive factory in Europe. Since then, company A has been moving its operations abroad through captive facilities, acquisitions, joint ventures, and contracts with third party companies. Thus, company A has three types of offshore operations (captive, partnership, and outsource).

The managers of Company A perceive differences in the management of these three types of offshoring. According to an interviewee, offshore captive provides the most control over operations and decisions. With the use of other offshoring types, operations management becomes more complex. For instance, in its offshore partnership, company A has to share decisions with its partner. With offshore outsourcing, company A has no control over decisions and operations. Coordination works when using specific contractual agreements in that type of offshore operation. Thus in terms of management and coordination of offshore operations, partnerships and the other types of outsourcing complicate the management of operations for company A.

In the early 1990s, company A decided to implement its growth strategy. The company decided to carry out the internationalization process as its main growth strategy. In that way, offshore operations contributed to the implementation of this strategy. Thus, company A highlights the main strategic role of offshore operations: it contributes to the implementation of an internationalization process, and consequently, the effectiveness of the company's growth strategy. For instance, by 2008 the company's net income grew from US\$200 million to more than US\$ 1,000 million.

Company A sees implementation of its management systems in facilities abroad as the main barrier to implementing offshore operations. Cultural differences, language, and the adaptation of expatriates are other barriers identified by company A. In order to implement offshore operations and overcome such barriers, company A has been providing special training to executives who will be expatriated. In general they are Brazilians with some knowledge of the country in which they will be posted.

Company A has also developed its own production system, which is transferred to facilities abroad to ensure standardization of production processes and products. According to an interviewee, company A uses the same operational logic of McDonald's. Regarding the company's path, the respondent emphasized that company A has been learning how to deal with cultural differences. This learning was central to the adaptation of expatriates and the implementation of management and production systems. In other words, understanding cultural differences was central to implementation of offshore operations. Finally, the company's position with regard to its production of a majority of its own components has contributed to the implementation of its offshore operation. Through this position company A has been able to sustain its international expansion for 20 years.

\subsection{Company B}

Company B is a Danish firm established in 1955 that produces hydraulic, electric, and such electronic systems as valves. Company B has more than 5,000 employees and over 20 manufacturing facilities with operations in more than 24 countries. Company B's offshoring experience started in 1987 through establishment of a joint venture. These days company B usually prefers captive type offshore operations so that it can ensure it controls operations. Except for a facility in China, it does not establish joint ventures. Company B manages its offshore operations with a hierarchical structure organized by product lines, thus different locations can share the same director. However, each facility has local function managers.

The main strategic role of offshore operations highlighted by company B is global production flexibility and cost. Offshore operations enable company B to move production of any product or component to where it is most advantageous. According to an interviewee, moving production from one location to another is very dynamic. At any time one location can become more advantageous than another. Thus production lines are moved among global locations frequently. But the main barrier to offshore operations for company B is related to this movement. When production is moved from one location to another, unused components are left at the previous location. This situation causes disagreement between locations because neither facility wants to assume that inventory.

To implement offshore operations and support flexibility among locations, company B has acquired knowledge about the customs operations and laws of the countries in which it has facilities. It has one 
office responsible for learning how customs works in these countries. Frequently an employee visits each country to obtain more specific information. In addition, company $\mathrm{B}$ promotes continuous training and human resources development focused on languages and the laws of international commerce.

During its path company B has been learning how to transfer businesses to countries that offer more benefits than Denmark. This accumulated knowledge has been essential to company B's implementation of offshore operations, and it achieves benefits from its global production flexibility. Finally, the company's position on maintaining captive operations has contributed to implementation of its offshore operations for it ensures that the company's objectives and goals are being met by the facilities abroad. Plus it avoids conflicts usually created by other options such as partnership and outsourcing.

\subsection{Company C}

Company $\mathrm{C}$ is a German company established in 1996 and dedicated to the production of chemicals. It has about 1,000 employees and more than six manufacturing facilities in six countries: Argentina, Brazil, China, France, India, and Italy. Company C has three types of offshore operations, and its executives perceive differences in the management of each type. Managing offshore captive is less complex than the others because it makes quality, standardization, and control of operations as a whole easier; partnership and outsourcing present additional management complexities and risks because these types do not allow direct control by company $\mathrm{C}$.

Costs and proximity to clients are two main strategic roles highlighted by company $\mathrm{C}$ as justification for offshore operations. They allow company $\mathrm{C}$ to produce in a location that offers the best margins and lowest costs. Offshore operations also allow company $\mathrm{C}$ to emphasize geographical proximity to its clients. These two advantages are central to achieving a better competitive position in the global market.
Legislative changes in the country where offshore facilities are located represent the main barrier highlighted by company C. For instance, an interviewee from company $\mathrm{C}$ commented about the changes in legislation that recently occurred in China. These changes have elevated costs to companies previously established in that country, sometimes making offshore operations there not economically viable. To deal with these additional costs, Company $\mathrm{C}$ has moved some operations from China to France. The main point is that when Company $\mathrm{C}$ started a facility in China, the government offered several incentives, but after three years, more rigorous legislation has made operations in that country more costly.

To implement its offshore operations, company $\mathrm{C}$ developed a management system that ensures integrated communication and information among locations abroad. Its management system also supports exchange of employees among locations to promote this integration. In addition, company $\mathrm{C}$ developed routines that ensure the exchange of information and experience. Offshore operations are also supported by an organization culture that has been developed during the company path. Even though company $\mathrm{C}$ is only 14 years old, it has accumulated 300 years of experience thanks to the founders of its predecessor's business. Finally, company C's position reallocating its production abroad has contributed to the implementation of its offshore operations. In addition, the company has been moving production among locations, its transfer of parts of its production from China to France for example. It, too, is promoting a more integrated global production through offshore operations.

\subsection{Cross-case analysis}

After analyzing each company separately, the cases were compared to identify similarities and differences. The comparisons are presented in Tables 1 and 2 and are briefly explained in the rest of this section. When examining offshore operation experiences of the companies, it seems there is little significant difference among them. However, it is possible to perceive that company B has the most experience with offshore operations. 
Table 1: Offshoring aspects

\begin{tabular}{|l|l|l|l|}
\hline Aspects & Company A & Company B & Company C \\
\hline $\begin{array}{l}\text { Experience on offshore } \\
\text { operations }\end{array}$ & Since 1990 & Since 1987 & Since 1996 \\
\hline $\begin{array}{l}\text { Types of offshore } \\
\text { operations }\end{array}$ & $\begin{array}{l}\text { Captive } \\
\text { Partnership } \\
\text { Outsource }\end{array}$ & Captive & $\begin{array}{l}\text { Captive } \\
\text { Partnership } \\
\text { Outsource }\end{array}$ \\
\hline $\begin{array}{l}\text { Perceive difference } \\
\text { on managing types of } \\
\text { offshore operations }\end{array}$ & Yes & Not applicable & Yes \\
\hline $\begin{array}{l}\text { Strategic role of offshore } \\
\text { operations }\end{array}$ & $\begin{array}{l}\text { Growth strategy through } \\
\text { internationalization } \\
\text { process }\end{array}$ & $\begin{array}{l}\text { Production flexibility and } \\
\text { costs }\end{array}$ & $\begin{array}{l}\text { Costs and proximity of } \\
\text { main clients }\end{array}$ \\
\hline $\begin{array}{l}\text { Barriers to implement } \\
\text { offshore operations }\end{array}$ & $\begin{array}{l}\text { Implementation of own } \\
\text { management system, } \\
\text { cultural difference, } \\
\text { language, and } \\
\text { adaptation of expatriates }\end{array}$ & Level of inventory & Legislation changes \\
\hline
\end{tabular}

Table 2: DC aspects

\begin{tabular}{|l|l|l|l|}
\hline Aspects & Company A & Company B & Company C \\
\hline $\begin{array}{l}\text { Capabilities developed } \\
\text { to implement offshore } \\
\text { operations }\end{array}$ & $\begin{array}{l}\text { Development of } \\
\text { expatriates }\end{array}$ & $\begin{array}{l}\text { Knowledge about } \\
\text { operation and law of } \\
\text { countries' customs }\end{array}$ & Management system \\
\hline $\begin{array}{l}\text { Organizational processes/ } \\
\text { routines developed }\end{array}$ & System of production & $\begin{array}{l}\text { Training and human } \\
\text { resource development }\end{array}$ & Information exchange \\
\hline $\begin{array}{l}\text { Company's trajectory } \\
\text { (path) }\end{array}$ & $\begin{array}{l}\text { Learning how to deal } \\
\text { with cultural differences }\end{array}$ & $\begin{array}{l}\text { Learning how to transfer } \\
\text { businesses to more } \\
\text { advantageous countries }\end{array}$ & Organization culture \\
\hline Positions & $\begin{array}{l}\text { Own production } \\
\text { of majority of its } \\
\text { components }\end{array}$ & Captive operations & Productions reallocation \\
\hline $\begin{array}{l}\text { Firm-specific processes } \\
\text { utilized }\end{array}$ & Leveraging and learning & Learning & Learning \\
\hline
\end{tabular}

While companies A and C utilize three types of offshore operations (captive, partnership, and outsourcing), company B prefers to utilize offshore captive exclusively. Its only exception is in China, and that is because of the restrictive legislation in that country. Company $\mathrm{A}$ and $\mathrm{C}$ perceive differences in the management of these distinctive types of offshore operation. They agree that offshore captive is less complex to manage and coordinate than offshore partnership and offshore outsourcing. In addition, company A and C observed that their influence over and control of decisions and operations decrease in offshore partnership and outsourcing, respectively. This characteristic can become a threat or risk to offshore operations. Additionally, to ensure stability of operations, all three companies prefer to employ their own hierarchical structure to control offshore operations.

Regarding the strategic role of offshore operations, it was possible to identify some distinctions in each 
company, particularly when comparing company A to companies B and C. Company A has been utilizing offshore operations to implement its internationalization process, which is aimed at achieving the objectives of its growth strategy. Thus, offshore operations have been contributing to company A's presence in several countries besides Brazil. Companies $B$ and $C$ clearly have been relying on offshore operations to achieve cost advantages. Achieving this aim is possible because of the global operation flexibility offshore operations allows. In other words, offshore operations permit companies B and $\mathrm{C}$ to move their production to locations that can be more advantageous in terms of costs.

Regarding barriers to the implementation of offshore operations, it was possible to identify some distinctions in each company. Company A perceives the most diverse numbers of barriers: implementation of its own management system, cultural difference, language, and the adaptation of expatriates. Conversely, companies B and C identify barriers that are focused on a specific aspect of offshore operations. Company B is focused on the barrier related to logistics operations, which highlights possible inventory problems among locations. As Company B constantly moves line production among global locations, it has encountered issues with inventories of components. This situation creates disagreement among facilities because no facility wants to assume a surplus of components. Company $\mathrm{C}$ considers legislation changes as the main barrier. These changes are increasing its operational costs. One way or another, Company $\mathrm{B}$ and $\mathrm{C}$ are both facing barriers that may result in additional costs. Thus, these barriers may be considered examples of costs not readily apparent prior to implementing offshore outsourcing (Ellran et al., 2008). This finding leads us to present the following proposition:

P1: Barriers to implementing and managing offshore operations are dynamic throughout the implementation and management of offshore operations.

As can be seen in Table 2, all companies perceive the contribution of DC elements and firm specific DC processes to the development of capabilities for managing offshore operations. But each company perceives that contribution differently. Company A considers its development of expatriates as the main resource and capability developed to implement offshore operations. The development of its own executives allows company A to deal with barriers faced in offshore operations. Knowledge is the main resource identified by company B when it comes to implementing offshore operations. That knowledge is focused on supporting the logistics of offshore operations among locations. Thus company B has been developing knowledge on how to operate each location and deal with legislation. This knowledge is seen as essential to ensure agility and flexibility of offshore operations among locations. Company $C$ regards its own management system as the main resource it developed to implement offshore operations. That system allows company $\mathrm{C}$ to achieve an integrated communication and information flow among locations abroad.

All companies identified contribution of organizational processes to developing capabilities to manage offshore operations; however, they focused on different processes. Company A identified its own system of production as the main process contributing to offshore operation. That system has been implemented in each location to ensure standardization of operations. Company B identified its training and human resource development as its main process. Unlike company A, company B's process is not focused on development of expatriates, but it is related to the development of employees in each offshore location. This process supports regular operations among locations, particularly those related to production transfer. Company $\mathrm{C}$ identified information exchange as the main process it developed. This process allows company $C$ to maintain coordination among locations. On the evidence of the above cross-case analysis and discussion, we present the following proposition:

P2: Organizational processes contribute to the development of capabilities for implementing and managing offshore operations; however the capabilities developed may vary among companies.

Path also contributes to the management of offshore operations for each company. During its path, company $\mathrm{A}$ has been accumulating learning related to dealing with cultural differences. This learning has contributed to implementing and managing offshore operations, particularly regarding the adaptation of expatriates and implementation of its own production system. Company B also considers learning accumulated during its path important. Unlike company $\mathrm{A}$, the learning company $\mathrm{B}$ sought was related to the transfer of businesses to countries that offer costs advantages. This learning is essential to its captive offshore operations. Company $\mathrm{C}$ attributed to its path the formation of an organizational culture that 
was fundamental to the implementation and management of offshore operations. On the evidence of the above cross-case analysis and discussion, we offer the following proposition:

P3: Development of resources and capabilities for implementing and managing offshore operations is a path-dependence process.

Concerning positions, each company has an individual perception of this element. However, all companies consider that their adopted position is contributing to offshore operations. Company A attributes its position on maintaining its own production of the majority of its components the main contributor to the implementation and management of its offshore operations. Company B attributes its position on utilizing offshore captive. In some way, the positions of companies A and B are similar. The two companies have a centralized posture in relation to offshore operations that orients the development of their capabilities. Company $\mathrm{C}$ considers its position on production reallocating as the main position contributing to management and development of its offshore operations. On the evidence of the above cross-case analysis and discussion we present the following proposition:

P4: Development of capabilities for implementing and managing offshore operations is dependent on a compa$n y$ 's past and current commitment to decisions regarding development of technology and specific assets.

Finally, firm-specific processes were also identified as contributors to development of capabilities for managing offshore operations. Company A uses leveraging and learning to replicate its own system of production among locations and make specific adaptations according to site needs. Company $\mathrm{B}$ recognizes learning as the main firm-specific process. According to that company, learning is a central process for performing operations at dispersed locations. Company B's employees are continuously stimulated to revise currents processes so as to generate new knowledge about tasks and routines used at offshore operations. Company $\mathrm{C}$ also recognizes learning as a main firm-specific process. Managers of each site meet periodically to share experiences and information. This practice contributes to the sharing of knowledge and learning on the management of offshore operations. It should be noted that the companies did not mention any observation regarding reconfiguration processes. On the evidence of the above cross-case analysis and discussion we present the following proposition:

P5: Firm-specific dynamic capabilities contribute to the development of capabilities for implementing and managing offshore operations; however, these dynamic capabilities vary among companies.

\section{CONCLUSION}

The main objective of this study was to understand how companies develop capabilities for managing offshore operations. The findings of this case study research have significant implications for offshore operations and DC.

Companies in this study perceive differences in managing the different types of offshore operations. Some studies attribute specific risks and barriers to each type of offshoring (e.g. Ellran et al., 2008; Kumar et al., 2009; Levina, 2007). Our findings indicate that different strategic roles of offshore operations may result in different perceptions of barriers, outcomes, and development of specific capabilities, findings that corroborate the arguments of earlier studies. The strategic role of offshore operations is also related to capabilities development. It is related to the argument that DC processes are driven by company strategy (Wang \& Ahmed, 2007). For instance, a company's decision on type of outsourcing (captive, outsourcing, or partnership) and the degree of offshore operations depends on the role of this process in the company's strategy (Metters, 2008).

All three elements of DC are perceived as contributors to the development of capabilities for implementing and managing offshore operations. This finding supports arguments that capability development is an outcome of dynamic capabilities (Wang \& Ahmed, 2007). Our findings also show that the development of capabilities is related to support and management of offshore operations. The literature suggests that the main function of DC is to allow a company to be able to fit continuously (e.g. Ambrosini \& Bowman, 2009).

Two specific DC processes were observed in this study: learning and leveraging. Indeed, learning was identified by companies as an aspect contributing to implementing and managing offshore operations. Companies in our study are searching for ways to replicate and disseminate processes from one location to another to support the implementation and management of offshore operations. In sum, there are common features on DC (elements) and firm- 
specific processes (DC processes). The common features inherent to DC and firm-specific processes may be dependent on the company's strategy (Wang \& Ahmed, 2007). Company A focuses on its own production system, company B focuses on training and human resource development, and company $C$ focuses on information exchange among locations.

This study contributes to practice by providing information on what kind of capabilities companies have been developing, and how they are developing these capabilities for managing offshore operations. Practitioners should first identify the strategic contribution of offshore operations to align it with the company's operations. It is also important to note that this study suggests a company's strategy as the main driver of DC and consequently the development of capabilities. One of the limitations of this study is its exploratory nature and the small number of cases. Thus we recommend complementing this study by examining a larger number of companies that have offshore operations. This research is one of the first studies to look at how companies develop capabilities for managing offshore operations. Future research studies on DC and offshore operations in other companies that engage in offshore operations can continue contributing to theory building and testing in this area.

\section{REFERENCES}

Ambrosini, V., Bowman, C. (2009), What are Dynamic Capabilities and are They a useful Construct in Strategic Management?, International Journal of Management Reviews, Vol. 11, No 1, pp. 29-49.

Askin O. Z., Masini, A. (2008), Effective Strategies for Internal Outsourcing and Offshoring of Business Services: An Empirical Investigation, Journal of Operations Management, Vol. 26, pp. 239-256.

Beugré C. D., Acar W. (2008), Offshoring and Cross-Border Interorganizational Relationships: A Justice Model, Decision Sciences, Vol. 39, pp. 445-468.

Bowman, C., Ambrosini, V. (2003), How the Resource-Based and the Dynamic Capability Views of the Firm Inform Corporate-Level Strategy, British Journal of Management, Vol. 14, pp. 289-303.

Bunyaratavej, K., et al. (2008). Multinational investment and host country development: Location efficiencies for services offshoring, Journal of World Business, Vol. 43, pp. 227-242.

Carmel, E., Agarwal, R. (2002), The Maturation of Offshore Sourcing of Information Technology Work, MIS Quarterly Executive, Vol. 1, No2, pp. 65-78.

Chakrabarty, S. (2006), Making Sense of the Sourcing and Shoring Maze: Various Outsourcing and Offshoring Alternatives, in Kehal, H. and Singh, V. P. (Eds.), Outsourcing and offshoring in the 21st Century: a socio economic perspective, Idea Group Publising, Hershey, PA, pp. 18-53.

Cooper, D. R., Schindler, P. S. (2003), Business Research Methods (8th ed). McGraw-Hill: New York.

Collis, D. J., Montgomery, C. A. (1994), Competing on Resources. Harvard Business Review, Vol. 37, No 4, pp. 118-128.

De Vita, G., Wang, C. L. (2006), Developing of outsourcing theory and practice: a taxonomy of outsourcing generations, in Kehal, H. and Singh, V. P. (Eds.), Outsourcing and offshoring in the 21st Century: a socio economic perspective, Idea Group Publising, Hershey, PA, pp. 1-17.

Doh, J. P. (2005), Offshore Outsourcing: Implications for International Business and Strategic Management Theory and Practice. Journal of Management Studies, Vol. 42, No3, pp. 695-704.

Duke University CIBER/Archstone Consulting (2005), First Biannual Offshoring Survey Results, Avaliable at: https:// offshoring.fuqua.duke.edu/pdfs/offshore_duke_particpant_ brochure_04-07-05_final.pdf (accessed 3 March 2009).

Duke University CIBER/Archstone Consulting (2006), Second Biannual Offshoring Survey Results, Avaliable at: https://offshoring.fuqua.duke.edu/pdfs/2nd_highlights.pdf (accessed 3 March 2009).

Duke University CIBER/ Booz Allen Hamilton (2007), Next Generation Offshoring - The Globalization of Innovation, Available at: https://offshoring.fuqua.duke.edu/research.jsp (accessed 3 March 2009).

Eisenhardt, K. M. (1989), Building Theories from Case Study Research, The Academy of Management Review, Vol. 14, pp. 532-550.

Eisenhardt, K. M., Martin, J. A. (2000), Dynamic Capabilities: What are They?, Strategic Management Journal, Vol. 21, pp. 1105-1122.

Ellran, L. M. et al. (2008), Offshore Outsourcing of Professional Services: A Transaction Cost Economics Perspective, Journal of Operations Management, Vol. 26, pp. 148-163.

Flick, U. (2002), An Introduction to Qualitative Research, 2nd edn. London, Sage.

Hagel III, J. (2004). Offshoring Goes on the Offensive. McKinsey Quarterly, Vol. 2, pp. 83-91.

Gião, P.R., Oliveira Jr., M.M. and Vasconcellos, E.P.D. (2008). Services offshore and its strategic effects on value chains. Brazilian Administration Review, Vol. 5, No. 3, 193-209.

Hagel III, J., Brown, J. S. (2005), The Only Sustainable Edge. Why Business Strategy Depends on Productive Friction and Dynamic Specialization, Harvard Business School Press, Boston, MA.

Helfat, C., Peteraf, M. (2003), The Dynamic Resource-Basead View: Capability Lifecycles, Strategic Management Journal, Vol. 24, pp. 997-1010.

Jahns, C. et al. (2006), Offshoring: Dimensions and Diffusion of a New Business Concept, Journal of Purchasing and Supply Management, Vol. 12, No 4, pp. 218-231. 
Kumar, K. et al. (2009), Offshoring and the global Distribution of Work: Implications for Task Interdependence Theory and Practice, Journal of International Business Studies, Vol. 40, pp. 642-667.

Levina, N. (2007), Leadership Practices for Achieving Collaboration in Global Sourcing, FSO, March, pp. 27-29.

Levina, N., Vaast, E. (2008), Innovating or Doing as Told? Status Differences and Overlapping Boundaries in Offshore Collaboration, MIS Quarterly, Vol. 32, No2, pp. 307-332.

Levy, D. L. (2005), Offshoring in the New Global Political Economy, Journal of Management Studies, Vol. 42, No3, pp. 685-693.

Lewin, A. Y., Peeters, C. (2006a), Offshoring Work: Business Hype or the Onset of Fundamental Transformation?, Long Range Planning, Vol. 39, No3, pp. 221-239.

Lewin, A. Y., Peeters, C. (2006b), The Top-Line Allure of Offshoring, Harvard Business Review, Vol. 84, №3, pp. 22-24.

Makadok, R. (2001), Toward a Synthesis of the Resource-Based and Dynamic-Capability Views of Rent Creation, Strategic Management Journal, Vol. 24, pp. 387-401.

Manning, S. et al. (2008), A Dynamic Perspective on Next-Generation Offshoring: The Global Sourcing of Science and Engineering Talent, Academy of Management Perspectives, Vol. 22, pp. 35-54.

Marcus, A. A., Anderson, M. H. (2006), A General Dynamic Capability: Does it Propagate Business and Social Competencies in the Retail Food Industry?, Journal of Management Studies, Vol. 43, No 1, pp. 19-43.

Maskell, P. et al. (2006), Learning paths to offshore outsourcing: From cost reduction to knowledge seeking, (CBS Center for Strategic Management and Globalization Working Paper 13/ 2006), Copenhagen Business School, Denmark.

Menon, A. G. (2008), Revisiting Dynamic Capability, IIMB Management Review, Vol. 20, № 1, pp. 22-33.

Meredith, J. (1998), Building Operations Management Theory through Case and Field Research, Journal of Operations Management, Vol. 16, pp. 441-454.

Metters, R. (2008), A Case Study of National Culture and Offshoring Services, International Journal of Operations \& Production Management, Vol. 28, pp. 727-747.

Moxon, R. W. (1975), The Motivation for Investment in Offshore Plants: The Case of the U.S. Electronics Industry, Journal of International Business Studies, Vol. 6, pp. 51-66

Niederman, F. (2005), International Business and MIS Approaches to Multinational Organizational Research: The Cases of Knowledge Transfer and IT Workforce Outsourcing, Journal of International Management, Vol. 11, pp. 187-200.

Olsen, K. B. (2006), Productivity impacts of offshoring and outsourcing: A review (OECD STI Working Paper 2006/ 1), OECD Directorate for Science, Technology and Industry, Paris.
Robinson, M., Kalakota, R. (2004), Offshore Outsourcing: Business Models, ROI and Best Practices, Mivar Press, Alpharetta, GA ( $2^{\text {nd }}$ edition).

Sapienza, H. J. et al. (2006), A Capabilities Perspective on the Effects of Early Internationalization on Firm Survival and Growth, Academy of Management Review, Vol. 31, pp. 914933.

Stake, R. (1998), Investigación con estudio de casos, Ediciones Morata, Madrid.

Stringfellow, A. et al. (2008), Invisible Costs in Offshoring Services Work, Journal of Operations Management, Vol. 26, pp. 167-179.

Sturgeon, T. J., Florida, R. (2000), Globalization and Jobs in the Automotive Industry. Services Offshoring Working Group Final Report, Massachusetts Institute of Technology, Boston, MA.

Teece, D. J., Pisano, G. (1994), The Dynamic Capabilities of Firms: An Introduction, Industrial and Corporate Change, Vol. 3, pp. 537-556.

Teece, D. et al. (1997), Dynamic capabilities and strategic management, in Foss, N. J. (Ed.), Resources firms and strategies a reader in the resource-based perspective, Oxford University Press, Oxford, pp. 268-285.

Terjesen, S. (2006), Outsourcing and offshoring of finance activities, in Kehal, H. and Singh, V. P. (Eds.), Outsourcing and offshoring in the 21st Century: a socio economic perspective, Idea Group Publising, Hershey, PA, pp. 209-228.

UNCTAD, (2004), World Investment Report 2004: The Shift Towards Services, United Nations, New York, Available at: http:// www.unctad.org (13 March 2009).

Venkatraman, N. (2004), Offshoring without Guilt, MIT Sloan Management Review, Vol. 45, №3, pp. 14-16.

Voss, C. et al. (2002), Case Research in Operations Management, International Journal of Operations \& Production Management, Vol. 22, pp. 195-219.

Zahra, S. A. et al. (2006), Entrepreneurship and Dynamic Capabilities: A Review, Model and Research Agenda, Journal of Management Studies, Vol. 43, pp. 917-955.

Wang, C. L., Ahmed, P. K. (2007), Dynamic Capabilities: A Review and Research Agenda, International Journal of Management Reviews, Vol. 9, Nº1, pp. 31-51.

Yin, R. K. (2003), Case Study Research: Design and Methods, Sage, Newbury Park, CA ( $3^{\text {th }}$ edition).

Youngdahl, W., Ramaswamy, K. (2008), Offshoring Knowledge and Service Work: A Conceptual Model and Research Agenda, Journal of Operations Management, Vol. 26, pp. 212-221.

Youngdahl, W. et al. (2008), Exploring New Research Frontiers in Offshoring Knowledge and Service Processes, Journal of Operations Management, Vol. 26, pp. 141-147. 


\section{AUTHOR'S BIOGRAPHY}

Vilmar Antonio Gonçalves Tondolo is Professor of Post-graduation Program in Business Administration at UNISUL - Universidade do Sul de Santa Catarina.

Hale Kaynak Director, Ph.D. Program, Professor of Operations Management at College of Business Administration, Department of Management at The University of Texas Pan-American

Yeda Swirski de Souza Associate Dean of Post-graduation Program in Business Administration at UNISINOS - Universidade do Vale do Rio dos Sinos.

Cláudia Cristina Bitencourt is Professor of Post-graduation Program in Business Administration at UNISINOS - Universidade do Vale do Rio dos Sinos. 